\title{
Processes of Receiving Western Astronomy in China and Vietnam
}

\author{
Anh Thuan Truong
}

For citation: Truong Anh Thuan. Processes of Receiving Western Astronomy in China and Vietnam. Vestnik of Saint Petersburg University. History, 2020, vol. 65, iss. 2, pp. 469-490.

https://doi.org/10.21638/11701/spbu02.2020.208

From the sixteenth century to the eighteenth century, in an effort to introduce and develop Christianity in China and Vietnam, Western missionaries, especially the Jesuit missionaries, found an effective way to realize this purpose: to use European scientific and technological achievements in order to satisfy the curiosity of kings, mandarins and intellectuals as well as their desire to learn new knowledge, thereby hoping to successfully attract the said social forces to follow the way which created a unique phenomenon: Christianity gradually entered the hearts of two nations of China and Vietnam along with the process of receiving Western scientific and technological achievements in these two countries. In particular, astronomy was one of the most typical fields. The article thoroughly analyzes means of introducing and results of receiving Western astronomy in China and Vietnam from the sixteenth century to the eighteenth century on the basis of the original historical data and studies by Chinese, Vietnamese and international scholars as well the application of historical research methods combined with comparative study methods. It elucidates the similarities and differences in the process of receiving Western astronomy in these two countries and contributes to the scholarship on the history of East-West cultural exchange in China and Vietnam in the sixteenth, seventeenth and eighteenth centuries.

Keywords: astronomy, the West, China, Vietnam, Christianity, Society of Jesus, mission, missionary.

\section{Внедрение достижений западной астрономии в Китае и Вьетнаме}

Ань Туан Чвонг

Для цитирования: Truong Anh Thuan. Processes of Receiving Western Astronomy in China and Vietnam // Вестник Санкт-Петербургского университета. История. 2020. Т.65. Вып. 2. С.469490. https://doi.org/10.21638/11701/spbu02.2020.208

Представленная статья выполнена в духе междисциплинарных исследований. Ее ключевым предметом является процесс распространения представлений западноевропейских ученых в азиатском регионе. Показано, что с XVI по XVIII в., стремясь внедрить и развить христианство в Китае и Вьетнаме, западные миссионеры, особенно миссионеры-иезуиты, нашли эффективный способ достижения этой цели. Использование

Anh Thuan Truong - PhD, The University of Da Nang, University of Science and Education, 459 Ton Duc Thang st., Danang city, Vietnam; tathuan@ued.udn.vn

Ань Туан Чьюнг - д-р философии, Университет Дананга, Университет науки и образования, 459, ул. Тон ТонкТханг, Дананг, Вьетнам; tathuan@ued.udn.vn

(C) Санкт-Петербургский государственный университет, 2020 
европейских научно-технических достижений и приобретение новых знаний в Китае и Вьетнаме, давали возможность надеяться на успешное привлечение королей, мандаринов и интеллигенции этих стран на путь, который привел к возникновению уникального явления: христианство постепенно вошло в культуру народов Китая и Вьетнама вместе с процессом внедрения и развития западных научно-технических достижений в этих странах. В частности, астрономия является одной из наиболее типичных областей этого процесса. На основе использования оригинальных исторических источников, изучения достижений китайских, вьетнамских и западных ученых, а также сочетания применения системы методов изучения исторической науки с другими методами, особенно со сравнительным методом исследования, в статье проводится тщательный анализ способов и результатов внедрения западной астрономии в Китае и Вьетнаме в XVI-XVIII вв. Результатом исследования стало выявление сходства и различия процесса проникновения западной астрономии в эти страны, а также попытка внести конкретный вклад в изучение истории культурного обмена между Востоком и Западом в Китае и Вьетнаме в XVI-XVIII вв.

Ключевые слова: астрономия, Запад, Китай, Вьетнам, христианство, Общество Иисуса, миссии, миссионер.

\section{Introduction}

In the sixteenth, seventeenth and eighteenth centuries, the presence of the Western missionaries, especially the Jesuit missionaries, in remote lands of the Far East, namely China and Vietnam, created a major change, not only in evangelization but also in the field of contemporary East-West cultural exchange. Formulation, creation and flexible application of the method of "missionary academic" not only helped Jesuit missionaries realize considerable success in the process of "Christianizing" these two countries but also gradually introduce many Western scientific and technological achievements, including astronomy, which were received by all walks of life in the societies of China and Vietnam, especially by kings, mandarins and intellectuals.

The analysis of original historical data as well as related scholarship shows that the process of receiving Western astronomy in China and Vietnam in the sixteenth, seventeenth and eighteenth centuries despite a few similarities differed with respect to the method and result.

${ }^{1}$ Missionary academic 學術傳教 is a term employed by Chinese researchers to refer to Jesuit missionaries using Western cultural and scientific achievements in fields of astronomy, geography, mathematics, physics, chemistry, military weapons, painting, literature, etc. to attract classes in Chinese society, especially the upper classes, to the faith in Christianity in the sixteenth and seventeenth centuries. According to scholar Shi Jinghuan 史靜寰, the initiator of this missionary method was Jesuit missionary Francois Xavier - the pioneer missionary in the Far East in the first half of the sixteenth century. From the end of the sixteenth century to the beginning of the seventeenth century, the "missionary academic" continued to be inherited and thoroughly applied by Jesuit missionaries, typically Matteo Ricci, Michele Ruggleri, contributing to the great success in the propagation of Christianity in China. See: Shi J.H. Tan Ming Qing zhi ji ru Hua Yesuhuishi di xueshu chuanjiao [The missionary academic ways of Jesuits into China at the end of the first period of Qing dynasty] // Neimenggu Shida xuebao [Journal of Inner Mongolia Normal University]. 1983. Vol. 3. P. 74-75; Liu Y. H. Li Madou deng zaoqi chuanjiaoshi di xueshu chuanjiao celue ji qi wenhua yiyi [Matteo Ricci and the other missionaries' tactical choice and Its Cultural values in late Ming dynasty] // Tianjin Shehui kexue [Tianjin Social Sciences]. 2003. Vol. 6. P. 130-135. 


\section{"Missionary academic" and the process of receiving the Western astronomy in China and Vietnam}

From the sixteenth century, the explosion of geographical discoveries associated with the advancements of maritime technology, especially the demands generated by the development of capitalism in Europe at that time, boosted the process of formation and major expansion of the trend of "going to the East", in which the leading force was the Western merchants and missionaries, aiming at the goal of "pepper and soul" ${ }^{2}$, meaning abundant goods and spices from the East and the faith of people of the kingdoms in this area. Documents recorded by the Westerners showed that in the sixteenth and seventeenth centuries, Spanish, Portuguese, Dutch, English, and French merchant ships followed one another in pursuit of trade with many countries in the Far East region, including China and Vietnam. Missionaries accompanied traders on these merchant ships. In this context, the process of introducing and receiving Western scientific and technological achievements in general, and astronomy in particular, took place naturally, associated with the pioneering role of Christian missionaries, especially Jesuit missionaries. From the outset, it also shaped the advantage of the mission path in the process of receiving achievements in Western astronomy in China and Vietnam at the time.

In fact, this process in the abovementioned countries originated from the introduction of the "missionary academic" method proposed by Jesuit missionaries and implemented in the sixteenth, seventeenth and eighteenth centuries. In the first half of the sixteenth century, when missionary work in China reached a dead end, Western missionaries still failed to access the inland with the Gospel. At the time, Christian societies in Macao were involved in a fierce debate about the choice of one of two methods: "missionary force" 3 or "missionary academic". However, in the second half of the sixteenth century, Jesuit missionaries initially successfully adopted the policy of "adaptation to indigenous culture" proposed by Alessandro Valignano 範禮安 5 . This line also emphasized the importance of acquiring cultural and historical values, customs and practices, especially the study and fluent use of languages and scripts of the nations under the mission for the success of evangelization ${ }^{6}$, and clearly showed the necessity to use European scientific knowledge as an effective way to conquer the faith of kings, mandarins, intellectuals and the people ${ }^{7}$ of the Eastern kingdoms. The thorough and creative application of this policy helped Mat-

2 Plattner F. A. Quand l'Europe cherchait l'Asie: Jésuites missionnaires (1541-1785). Paris, 1954. P. 11.

3 From 1565 to 1569 , when the mission in China faced many difficulties, some Western missionaries such as Ribera, Melchior Nunes Barreto, and Alonso Sanchez said that it was necessary to use force to open the door of China for Christianity to enter. This idea marked the birth of the "missionary force" policy. See: Dunne G. H. Generation of Giants: The story of the Jesuits in China in the last Decades of the Ming dynasty. Notre Dame, 1962. P. 16-17; Pei H.X., Xiao R. H. Tianzhujiao shiliu shiji zai Hua chuanjiaozhi [Catholicism in the sixteenth century in China missionary annals]. Shanghai, 1938. P.231.

${ }^{4}$ Shi J.H. Tan Ming Qing zhi ji ru Hua Yesuhuishi di xueshu chuanjiao [The missionary academic ways of Jesuits into China at the end of the first period of Qing dynasty]. P. 74.

5 Alessandro Valignano 範禮安 (1539-1606) is a Jesuit missionary, an Italian. During his mission, Valignano mainly conducted the mission in the Far East, especially Goa (India), Macau (China) and Japan. For the biography of Alessadro Valignano, see more: Morgan J.F. The Japanese and the Jesuits: Alessandro Valignano in Sixteenth Century Japan. New York, 1993; O'Malley J. W., Bailey C. A., Harris S. J., Kennedy T. F. The Jesuits: Cultures, Sciences, and the Arts, 1540-1773. Vol. 1. Torronto, 1999. P. 336-351.

${ }^{6}$ Li M.D., Jin N. G., He G. J., Wang Z.Z., Li S. Li Madou Zhongguo zhaji (Shang ce) [Matteo Ricci's Notes on China (vol. 1)]. Beijing, 1983. P. 142-143.

7 Bangert W. V. A History of the Society of Jesus. Saint Louis, 1972. P. 157. 
teo Ricci 利瑪竇 ${ }^{8}$, Francesco Buzomi ${ }^{9}$ and other Jesuit missionaries to gradually achieve the goal of fully opening the door of China and Vietnam in order to "nurture" the first Christian "seeds" in these two missionary areas. In that process, they further realized that the most effective way to attract the Chinese and the Vietnamese to Christianity, especially kings, mandarins and intellectuals, was to use academic thought as well as Western scientific and technological knowledge and achievements. Matteo Ricci, the first Jesuit missionary who successfully applied the policy of "missionary academic" in China from the late sixteenth century to the early seventeenth century, even asserted that to ensure the success of the mission at first it was necessary to receive the respect of the Chinese. There was nothing better for the purpose than a Western academic. And once people's hearts were conquered by the academic, they would definitely believe in Christianity ${ }^{10}$. It should be noted that, compared to other religious orders, the most prominent characteristic of the Jesuit missionaries was the belief in the importance of education. Before traveling to distant lands to carry out evangelization, Jesuits often embarked on a systematic, professional and formal educational process for over ten years. Accordingly, they not only had to study theology but also had to choose among types of natural science knowledge ${ }^{11}$. Therefore, most of the missionaries of this religious order had erudite knowledge. That was one of favorable prerequisites for the Jesuits to assert their leading role in spreading and extending the influence of Western science and technology in general, and astronomy in particular, in China and Vietnam through their missionary process in the sixteenth, seventeenth and eighteenth centuries.

Although the process of receiving Western astronomy in China and Vietnam from the sixteenth to the eighteenth centuries was associated with the method of "missionary academic", it differed in the two countries. In China, respectful attitude of the rulers and upper class to astronomy as well as their curiosity for "strange items"12, especially

${ }^{8}$ Mateo Ricci 利瑪竇 (1552-1610) was an Italian Jesuit missionary who laid the foundation of the Jesuit mission in China. He served as Catholic Archbishop in China from 1597 to 1610. Since 1582, he began to learn Chinese and Chinese culture. He was known as the Western who was knowledgeable about Chinese culture in the sixteenth century. For Mateo Ricci, see: Fontana M. Matteo Ricci: A Jesuit in the Ming Court. Maryland, 2010; Po-chia Hsia R. Matteo Ricci and the Catholic Mission to China, 1583-1610: A short history with document. Indianapolis, 2016; Laven M. Mission to China: Matteo Ricci and the Jesuit Encounter with the East. London, 2011.

${ }^{9}$ Francesco Buzomi was considered to be the first founder of Christianity in Cochinchina, Vietnam, in the first half of the seventeenth century. He was born in 1576 in Naples (Italy), served as a missionary in Japan and worked as a professor of theology in Macao before going to Cochinchina, Vietnam in 1615. Of his 24 years of service in Cochinchina (1615-1639), the first 10 years (1615-1624) was relatively favorable, but the next 14 years were marked by difficulties and challenges (1625-1639). In 1639 Lord Nguyen Phuc Lan asked him to return to Macao to play a role for the Lord. He fell ill and died in Macao that year when the work was not finished. See: Do Q. C. Lịch sử chũ Quốc ngũ̃ (1620-1659) [History of the Romanized Vietnamese script (1620-1659)]. SàiGòn, 1972. P.24; Rhodes A. Divers Voyages et Missions. Paris, 1653. P. 67-70.

${ }^{10}$ Fei L.Z., Feng C.J. Ru Hua Yesuhuishi liezhuan [Biographies of Jesuits entering China]. Shanghai, 1938. P. 42; Ricci M., Trigault N. China in the sixteenth century: the journals of Matthew Ricci, 1583-1610. New York, 1953. P. 325.

${ }^{11} \mathrm{Du}$ Halde J. B. Yesuhuishi Zhongguo shujianji: Zhongguo huiyilu (Di yi juan) [Jesuit missionaries letter collection in China: China memoirs (vol. 1)]. Zhengzhou, 2001. P. 3.

${ }^{12}$ In the eyes of the Chinese in the sixteenth, seventeenth and eighteenth centuries, items of Western origin, especially those related to science and technology such as watches, lenses, and telescopes were strange, aroused curiosity, so they were called "strange items". See: Shi J.H. Tan Ming Qing zhi ji ru Hua 
astronomical instruments ${ }^{13}$ originated from the West, was recognized, so during the missionary period in China, Jesuit missionaries often offered these instruments as gifts to the kings, mandarins, and intellectuals. According to historical records from 1598 to 1600, Matteo Ricci in the course of his mission upon arrival in different lands in China, such as Zhaoqing 肇慶, Shaozhou 韶州, Nanchang 南昌, Nanjing 南京, often carried and displayed at his residence a wide range of Western astronomical instruments - celestial globe, terrestrial globe, quadrant, compass and sun-dial - at the same time using them as gifts for local officials ${ }^{14}$. In addition, he also paid special attention to maximizing his astronomy expertise to create a reputation and make an impression on the rulers and the upper class in the Chinese society at that time ${ }^{15}$. In 1601, during his second visit to Beijing, Matteo Ricci along with Diego de Pantoja 龐迪我 ${ }^{16}$ and 8 other Jesuit missionaries ${ }^{17}$ brought 34 Western gifts of 15 different categories ${ }^{18}$ to offer to Emperor Wanli 萬曆, which included some types of astronomical instruments: a striking clock, an armillary sphere, a triangular prism ${ }^{19}$. During the Qing dynasty, Jesuit missionaries Philippe Marie Grimaldi 閔明我 ${ }^{20}$, Ferdinand Verbiest 南懷仁 ${ }^{21}$, Jean Francois Gerbil-

Yesuhuishi di xueshu chuanjiao [The missionary academic ways of Jesuits into China at the end of the first period of Qing dynasty]. P. 76-77.

${ }^{13}$ A letter from the French missioner Louis Porquet written on 14 October 1719 mentioned a wide range of Western items that made Chinese people become very curious and interested, in which instruments related to astronomical fields such as watches, telescopes, microscopes, and lense types accounted for the large quantity. See: Du Halde J. B. Yesuhuishi Zhongguo shujianji... [(vol. 2)]. Zhengzhou, 2001. P. 214.

14 Song J.L. Ming mo liju yu xixue dong jian [The Calendar Bureau and the introduction of Western science in the end of Ming dynasty] // Xinyang Shifan Xueyuan Xuebao (Zhexue Shehui kexue ban) [Journal of Xinyang Normal University (Philosophy and Social Sciences Edition)]. 2006. Vol.4. P. 121; Guo F.X. Types and sources of scientific instruments in the Imperial Court of the early Qing dynasty // Asian Studies. 2015. Vol.3. P. 128.

${ }^{15}$ Pfister L. Notices biographiques et bibliographiques sur les jésuites de l'ancienne mission de Chine. Vol. 1. Shanghai, 1932. P. 23.

16 Diego de Pantoja 龐迪我 (1571-1618) was a Spanish Jesuit missionary operating in China during the early seventeenth century. He joined the Jesuits in 1589 and went to China to preach in 1599. In 1601, he went to Beijing with Matteo Ricci and other Jesuit missionaries. Here, with an understanding of astronomy and mathematics, he helped Ming dynasty revise the calendar. In 1617, he was expelled from mainland China, returned to Macao and died here in 1618. See: Ricci M., Trigault N. China in the sixteenth century: the journals of Matthew Ricci, 1583-1610. New York, 1953. P.355; Pfister L. Notices biographiques et bibliographiques sur les jésuites de l’ancienne mission de Chine. Vol. 1. Shanghai, 1932. P. 69-73.

${ }_{17}$ Zhu Q. Z. Zhu Qianzhi wenji (Di qi juan) [Zhu Qianzhi’s collection of works (vol. 7)]. Fujian, 2002. P. 69.

${ }^{18}$ Han Q., Wu M. Xi chao chong zheng ji Xi chao ding an (wai san zhong). Beijing, 2006. P. 20.

${ }^{19} \mathrm{Li}$ J. P. Qing chu shi da yuan an [The ten great unjust cases in the early Qing dynasty]. Beijing, 1993. P. 198; Pfister L. Notices biographiques et bibliographiques sur les jésuites de l'ancienne mission de Chine. Vol. 1. P.28-29.

20 Philippe Marie Grimaldi 閔明我 (1639-1712) was a Jesuit missionary operating in China from the second half of the 17th century to the beginning of the eighteenth century. He joined the Jesuits in 1657 and went to Macao to preach in 1659. In 1671, he went to Beijing to assist the missionary Ferdinand Verbiest in astronomical observation and calendar calculation and until 1688, when Ferdinand Verbiest died, he held the position of Director of the Calendar Bureau. During his working time there, he made certain contributions to bringing Western scientific and technological achievements, especially astronomy to the Chinese people. See: Pfister L. Notices biographiques et bibliographiques sur les jésuites de l'ancienne mission de Chine. Vol. 1. P.372-376; Treadgold D. W. The West in Russia and China: Religious and Secular Thought in Modern Times. Vol. 2. Cambridge, 1973. P. 27.

${ }^{21}$ Ferdinand Verbiest 南懷仁 (1623-1688), was a Belgian Jesuit missionary, one of the people who played a major role in spreading Western scientific and technological achievements in China in the $17^{\text {th }}$ century. In 1641, he joined the Jesuits. In 1658, he and other missionaries traveled to the Far East to 
lon 張誠 ${ }^{22}$, Louis Le Comte 李明 ${ }^{23}$, Jean de Fontaney 洪若翰 ${ }^{24}$, Joachim Bouvet 白晉 ${ }^{25}$, Hubert Cousin de Mericourt 李俊賢 ${ }^{26}$ and Joseph Panzi 潘廷璋 ${ }^{27}$ while working at courts during the reign of Kangxi 康熙 (1662-1722) and Qianlong 乾隆 (1735-1796) many times offered to these two emperors clock types as well as instruments for measuring astronomical phenomena ${ }^{28}$.

In Vietnam, in the sixteenth, seventeenth and eighteenth centuries, to approach the kings, mandarins and native intellectuals, the Jesuit missionaries working in the country also used the method of offering gifts. However, if in China, European gifts, especially astronomical measuring items and time measuring instruments presented by Jesuit missionaries to the king and mandarins of Ming and Qing dynasties were relatively various

evangelize and arrived in Macao in 1659. During his time in China from 1659 until his death (1688), he served as Director of the Qing Bureau of Astronomy, helped the dynasty conduct many astronomical tasks such as making catalogues of stars, creating 6 large astronomical instruments that are still displayed today on the Beijing Observatory. To find out his whole life and career, see: Pfister L. Notices biographiques et bibliographiques sur les jésuites de l'ancienne mission de Chine. Vol. 1. P.338-362; Spence J.D. Emperor of China: Self-Portrait of K’ang-hsi. New York, 1988. P. 15-16.

${ }^{22}$ Jean Francois Gerbillon 張誠 was a French Jesuit missionary, born in 1654 in Verdun. In 1670, he joined the Jesuits. He went to China in 1687 to the mission. During his time in the country, he once held an important position in the Qing dynasty. He died in Beijing in 1770. On the life and career of Jean Francois Gerbillon, see: Pfister L. Notices biographiques et bibliographiques sur les jésuites de l'ancienne mission de Chine. Vol. 1. P. 443-452.

${ }^{23}$ Louis Le Comte 李明 was a French Jesuit missionary, born in 1655 in Bordeaux. He joined the Jesuits in 1671. In 1687, he went to China to the mission. In 1790, he returned to Europe and never came back to China. He died in Bordeaux in 1728. On the life and career of Louis Le Comte, see: Pfister L. Notices biographiques et bibliographiques sur les jésuites de l'ancienne mission de Chine. Vol. 1. P. 440-443.

${ }^{24}$ Jean de Fontaney 洪若翰 was a French Jesuit missionary, operating in China from the late seventeenth to the first half of the eighteenth century. He was born in 1643 in Bretagne. In 1658, he joined the Jesuits. He went to China in 1687 to the mission with some other French Jesuit missionaries. During his mission in China, he set foot in various lands such as Guangzhou 廣州, Ningbo 寧波, Beijing 北京, Nanjing 南京. In 1703, he returned to Europe and worked in La Fléche, France, until his death (1710). See: Pfister L. Notices biographiques et bibliographiques sur les jésuites de l'ancienne mission de Chine. Vol. 1. P. 420-434.

${ }^{25}$ Joachim Bouvet 白晉 (1656-1730), was a French Jesuit missionary, operating in China from the late seventeenth to early eighteenth centuries. In 1678, he joined the Jesuits and set out for Chinese mission in 1687. During his mission in this country, by compiling and translating Western science and technology books into Chinese, he made significant contributions to the East-West cultural exodus in contemporary China. About the life and career of Joachim Bouvet, see: Pfister L. Notices biographiques et bibliographiques sur les jésuites de l'ancienne mission de Chine. Vol. 1. P. 434-440.

${ }^{26}$ Hubert Cousin de Mericourt 李俊賢 (1729-1774) was a French Jesuit missionary operating in China in the late eighteenth century. In 1754, he joined the Jesuits and set out for Chinese mission in 1773. During the period of work in the country, he used to manufacture watches and a number of other tools. He died in Beijing in 1774. See: Pfister L. Notices biographiques et bibliographiques sur les jésuites de l'ancienne mission de Chine. Vol. 2. P. 974.

27 Joseph Panzi 潘廷璋 (born before or after 1733, died before 1812) was an Italian Jesuit missionary who went to China to evangelize in 1771, making a significant contribution to introducing Western scientific and technological achievements into China at the end of the eighteenth century - early nineteenth century. On the life and career of Joseph Panzi, see: Pfister L. Notices biographiques et bibliographiques sur les jésuites de l'ancienne mission de Chine. Vol. 2. P.971-974.

28 Pfister L. Notices biographiques et bibliographiques sur les jésuites de l’ancienne mission de Chine. Vol. 1. P.373; Thomaz de Bossierre M. Y. Yesuhuishi Zhang Cheng - Luyi shisi pai wang Zhongguo de wu wei shuxuejia zhiyi [Jesuit Jean-François Gerbillon - One of the five mathematicians sent by Louis XIV to China]. Zhengzhou, 2009. P. 29; Gerbillon J. F. Zhang Cheng riji [Jean-François Gerbillon's diary]. Beijing, 1973. P. 62-63, 71; Bai J., Ma X. X. Kangxi di chuan [Biography of Emperor Kangxi]. Zhuhai, 1995. P.31-32; Južnič S. Liu Songling - Jiu Yesuhui zai jing zuihou yi wei weida de tianwenxuejia [Hallerstein — The last great Astronomer of the Old Jesuit in Beijing]. Shanghai, 2014. P. 132-133. 
and abundant, in Vietnam their number was limited. Since Vietnam was quite far from the missionary center in Macao, Western merchant ships (from Portugal, Netherlands, England, France) came here only a few times a year, sometimes even didn't come to trade for years, so missionaries traveling by such ships to this country had fewer opportunities to land at Vietnamese trading ports. According to some records from contemporary Jesuit missionaries, such items as pearls, gold ${ }^{29}$, clocks and a very small number of Western science books ${ }^{30}$ were commonly used as gifts by Jesuits in Vietnam. As for astronomical instruments, there is no record. Meanwhile, among the goods that European traders brought to Vietnam at this stage, there were no compasses, telescopes, microscopes, lenses or astronomical instruments from the West ${ }^{31}$. In China, the process of manufacturing astronomical instruments $\mathrm{s}^{32}$ as well as compiling and translating European bibliography on astronomy into Chinese by Jesuit missionaries ${ }^{33}$ was vigorous, which speeded up the reception of Western astronomy in this country and helped achieve great results, in contrast to Vietnam, where such activities of Western missionaries were not documented. Although Jesuit missionaries in Vietnam were engaged in the compilation and translation of European bibliographies into the native language in the seventeenth and eighteenth centuries, they only focused on the fields of Bible, theology and Christian rituals ${ }^{34}$, whereas the fields of science and technology, especially astronomy, remained completely outside of their scope. However, that didn't mean that Vietnamese people did not have any opportunity to access Western astronomy in the sixteenth, seventeenth and eighteenth centuries.

29 Saccano M. Relation des progrèz de la Foy au royaume de la Cochinchine ès années 1646 et 1647. Paris, 1653. P. 65-66, 111-113.

30 Rhodes A.: 1) Divers Voyages et Missions. Paris, 1653. P. 92; 2) Histoire du Royaume de Tunquin. Lyon, 1651. P. 152-153.

31 Manguin P. Y. Les Portugais sur les côtes du Viet-Nam et du Campa. Paris, 1972. P.248-249; Mantienne F. Les relations politiques et commerciales entre la France et la péninsule Indochinoise (XVIIe siècle). Paris, 2001. P. 259.

$32 X u$ J.L. Ershisi shi quanyi (Di san ce) [The full translation of twenty-four sets of history books (vol. 3)]. Shanghai, 2004. P. 436; Zhang B. C. Ming Qing cetian yiqi zhi Ouhua [The Europeanization of astronomical instruments in the Ming and Qing China]. Shenyang, 2000. P. 161-170. See more: Yao C.S. Qingdai Qintianjian de tianwen gongzuo [Astronomy activities of the Qing dynasty Qintianjian] // Guangxi Minzu Xueyuan xuebao (Ziran kexue ban) [Journal of Guangxi University for Nationalities (Natural Science Edition)]. 2004. Vol.2. P.44; Needham J., Wang L. Science and Civilisation in China. Vol.3. Cambridge, 1959. P. 451-452.

${ }^{3} X u$ Z.Z. Ming Qing jian Yesuhuishi zheyi tiyao [Summary of Jesuits translated works in Ming and Qing dynasties]. Shanghai, 1949; Ma Z. T. "Xixue Dong jian” yu "Dongxue Xi jian” — Ming mo Qing chu chuanjiaoshi keji fanyi de lishi wenhua yujing [Historical and cultural context of missionary sci-tech translation in late Ming and early Qing dynasty] // Yuwen xuekan [Journal of Language and Literature Studies]. 2010. Vol. 8. P. 83; Hu X. Y. Cong "Ming Qing jian Yesuhuishi yizhu tiyao" kan Zhong Xi xueshu jiaoliu [On Chinese and Western Academic Exchange from the perspective of "Summary of Jesuits translated works in Ming and Qing dynasties"] // Sichuan Tushuguan xuebao [Journal of The Sichuan Society for Library Science]. 1996. Vol. 6. P. 78. See more: Bernard H. Les Adaptations Chinoises D'ouvrages Europeens: Bibliographie Chronologique Depuis la Venue des Portugais à Canton Jusquà la Mission Française de Pékin 1514-1688 // Monumenta Serica. 1945. Vol. 10. P. 1-57, 309-388.

34 In the early seventeenth century, only a few years after arriving in CochinChina, Jesuits immediately composed a book of catechism in Nôm script to serve the mission. Later, with the aim of providing catechism books to the parishioners, Alexandre de Rhodes, Amaral, Fontes, Borges, Barbosa, composed or translated some Christian books. In particular, the number of books translated and edited by Majorica were maximum 48 volumes. See: Truong B. C. Lịch sử phát triển Công giáo Việt Nam [History of Catholic development in Vietnam] // Nguyệt san Công giáo và Dân tộc [Monthly Journal of Catholicism and Ethnicity]. 1999. Vol. 56 (8). P. 114-115. 
In fact, at this stage, Western astronomy was introduced to the country and initially accepted by Vietnamese kings, mandarins, and intellectuals by two methods: firstly through Jesuit missionaries who explicitly discussed and explained the knowledge of Western astronomy to the rulers of Vietnam ${ }^{35}$, and secondly - by missionaries of this order who, on many occasions, calculated the imminent solar and lunar eclipses and outlined them in drawings informing the king and local officials, and also debated a number of issues related to these phenomena with Vietnamese astronomers ${ }^{36}$.

In short, from the sixteenth to the eighteenth centuries, the method of "missionary academic" devised and implemented by Jesuit missionaries became a key factor leading to the reception of the Western astronomy in China and Vietnam. However, in these two countries, the specific realization of this method was different. In China, the policy of "missionary academic" was concretized by Jesuit missionaries who offered and manufactured new Western astronomical instruments; repaired and improved Chinese traditional astronomical instruments in accordance with Western system; compiled and translated European astronomical books into the Chinese language with the desire to promote access to and reception of the Western astronomy by the Chinese people, especially kings, mandarins and intellectuals. By contrast, in Vietnam, Western astronomy came to the Vietnamese people by simpler and less profound means as Jesuit missionaries in the country interpreted the Western astronomical theory to indigenous rulers and calculated and predicted solar and lunar eclipses. The difference in the process of applying the "missionary academic" method in China and Vietnam mentioned above led to differences in the level and results of receiving Western astronomy in these two countries in the sixteenth, seventeenth and eighteenth centuries.

\section{The results of reception of Western astronomy in China and Vietnam}

From the sixteenth century to the eighteenth century, to realize the goal of bringing Christianity, missionaries in China and Vietnam introduced and developed Western scientific and technological achievements, especially astronomy, following in the footsteps of Jesuits by entering the palace as well as other localities in these two missionary lands in order to attract the kings, mandarins and indigenous intellectuals and arouse their curiosity and admiration for the accuracy of astronomical calculations and forecasts. In fact, during sixteenth, seventeenth and eighteenth centuries, the results of this process far exceeded the expectation of Jesuit missionaries: Christianity gradually entered the hearts of two nations of China and Vietnam being immensely facilitated by a simultaneous process of the reception of Western astronomical innovations.

In China, despite the prohibition of Christianity becoming increasingly severe and intense, the emperors of Ming and Qing dynasties adopted an open-minded attitude to the employment of Jesuit missionaries at the Bureau of Astronomy to take over astronomical and calendar works in the seventeenth and eighteenth centuries, which made

35 Baldinotti G. La Relation sur le Tonkin du P. Baldinotti // Bulletin de l'Ecole française d'ExtrêmeOrient. 1903. Vol.3. P. 71-78; Rhodes A. Histoire du Royaume de Tunquin. Lyon, 1651. P. 152-153.

36 Borri $C$. Relation de la nouvelle mission des pères de la compagnie de Jésus au royaume de la Cochin Chine // Bulletin des Amis du Vieux Hué. 1931. Vol.3-4. P. 376-381; Luis G. Histoire de ce qui s'est passé en Éthiopie, Malabar, Brasil, et les Indes Orientales. Paris, 1628. P. 122-123. 
the process of receiving Western astronomy in the country direct and continuous but also brought about a number of positive results expressed in the following specific aspects.

Firstly, Western astronomy made its way into China through the correction and compilation of the Calendar made by Jesuit missionaries in the late Ming dynasty period and early Qing dynasty period. During the late Ming dynasty period (early seventeenth century), before the introduction of astronomy and Western math calendar associated with Christianity, there were many contemporary mandarins and intellectuals interested in the new astronomical knowledge from Europe, among whom Li Zhizao 李之藻 ${ }^{37}$ and Xu Guangqi 徐光啟 ${ }^{38}$ should be mentioned first ${ }^{39}$. Realizing the advanced nature of Western astronomy compared to the traditional astronomical platform of the Chinese at the time, they constantly petitioned to the Emperor of Ming dynasty for approval of the establishment of a new specialized body and use of the Western method to revise the applicable Datong Calendar 大統歷 that had many errors ${ }^{40}$. It was approved by Chongzhen 崇禎 — the last king of Ming dynasty. In 1629, Calendar Bureau 歷局 was founded, and some Jesuit missionaries ${ }^{41}$ were invited to revise Datong Calendar 大統歷. With the constant efforts of the missionaries as well as of some Chinese astronomers familiar with Western math calendar, by 1634, the Western-style revised calendar had been completed and called Chongzhen Calendar 崇禎曆書. It would not be an exaggeration to say that it was an encyclopedia introducing the contemporary Western astronomy into China. The

37 Li Zhizao 李之藻 (1565-1630) was a Chinese mandarin and scientist at the end of the sixteenth century - the beginning of the seventeenth century. He showed his openness to the achievements of Western civilization through his association with the Jesuit missionaries and collaboration in preparation and translation of many Western scientific and technological bibliographies into Chinese language, importantly contributing to promoting the process of East-West cultural exchange in China in the late Ming period. About his life and career, see: Gerstl A., Strasáková M. Unresolved Border, Land and Maritime Disputes in Southeast Asia: Bi-and Multilateral Conflict Resolution Approaches and ASEAN's Centrality. Leiden, 2016. P.179; Liang Z. J. Shuxuejia zhuanlue cidian [Biographical sketch dictionary of mathematicians]. Jinan, 1989. P. 384.

38 Xu Guangqi 徐光啟 (1562-1633) was a mandarin, a mathematician, an astronomer and an agronomist in China at the late sixteenth and early seventeenth centuries. He was known for being a progressive and open-minded person in receiving achievements of the Western civilization, working together with Jesuit missionaries on preparation and translation of some European scientific and technical documents to the Chinese language, importantly contributing to promoting the process of East-West cultural exchange in China in the late Ming period. About the life and career of Xu Guangqi, see: Jami C., Engelfriet P., Blue G. Statecraft and Intellectual Renewal in Late Ming China: The Cross-Cultural Synthesis of Xu Guangqi (1562-1633). Leiden, 2001. P. 19, 33, 35, 44-45, 48-49, 93-94, 309, 400, 409; Needham J., Bray F. Science and Civilisation in China. Vol. 6. Cambridge, 1984. P. 64-65.

${ }^{39}$ Liang Q. C. Zhongguo jin san bai nian xueshu shi [Academical history of China of the last three hundred years]. Taiyuan, 2001. P.321.

40 Fang H. Li Zhizao yanjiu [Li Zhizao Research]. Taibei, 1966. P. 179; Xu J. L. Ershisi shi quanyi (Di san ce) [The full translation of twenty-four sets of History books (vol. 3)]. P. 424.

41 When Calendar Bureau 歷局 was founded in 1629, two Jesuit missionaries, Niccolo Longobardi 龍 華民 and Johann Schreck 鄧玉涵, were involved in revising the calendar here. However, because Niccolo Longobardi paid more attention to the mission, in fact, the work of revising the calendar was in charge of Johann Schreck. After Johann Schreck died (1630), two other Jesuit missioners named Johann Adam Schall von Bell 湯若望 and Giacomo Rho 羅雅谷 continued to revise the calendar here. Thus, from 1629 until 1634, the year of completion of the revision of Datong Calendar 大統歷, there had been four Jesuit missionaries working at Calendar Bureau. See: Xu G. Q., Wang Z.M. Xu Guangqi ji (Xia ce) [The complete works of Xu Guangqi (vol. 2)], Shanghai, 1984. P.343-344, 427-428; Song J. L. Ming mo liju yu Xixue Dong jian [The Calendar Bureau and the introduction of Western science in the end of Ming dynasty] // Xinyang Shifan Xueyuan Xuebao (Zhexue Shehui kexue ban) [Journal of Xinyang Normal University (Philosophy and Social Sciences Edition)]. 2006. Vol.4. P.122-123. 
first part of the calendar presented the theories of the Western astronomy, while the second part included the calculated and compiled astronomical tables on the basis of astronomical theories in the first part. Chongzhen Calendar introduced to China the theory of the universe system by the Danish astronomer Tycho Brahe for the first time. Besides, the knowledge related to our planet - sphericity of the Earth; longitude and latitude of the Earth; methods of calculation and measurement - was accepted by the Chinese also through Chongzhen Calendar, which contributed to the joint development path of the world astronomy at the time. In particular, the head of the Calendar Bureau 歷局 Xu Guangqi 徐光啟 taught Western astronomy to students at the Bureau of Astronomy of the Ming dynasty with the purpose of equipping them with the principles and methods of calculating the Western calendar ${ }^{42}$.

However, when this calendar was not yet ready for practical use and considerable benefits to the mission as Jesuits had expected, the political event of "dynasty replacement" occurred: the Ming dynasty collapsed, and the Manchu people started to rule China in 1644. It swept away as a flood all achievements by the Jesuit missionaries with respect to astronomical knowledge. In such a context, the missionary Johann Adam Schall von Bell - one of the most important people directly in charge of revising the calendar in the late Ming dynasty - with other Jesuit missionaries decided to take a bold and risky step: to continue using the Western astronomical knowledge, and through revision and compilation of the calendar reach out to the rulers of the Qing dynasty, a newly emerged dynasty skeptical about everything related to the Ming dynasty, in order to seek for the smallest opportunity to stay in China to preach the Gospel. As Helmer Aslaksen wrote in his work "The Mathematics of the Chinese Calendar", "In 1644 he went to the new Qing rulers and presented his calculations for an upcoming solar eclipse on September 1. At this time the Manchus were suspicious of the Chinese, but Schall told them that they could trust him, because he was a foreigner like them. This worked, in spite of the fact that other Jesuits were busy supporting Ming loyalists in the South. He challenged the Chinese and the Muslim astronomers in the Bureau, and again the Jesuits' calculations were best" 43 . In the following year (1645), the missionary Johann Adam Schall von Bell respectfully offered the so called Shixian Calendar 時憲歷, which was compiled according to the new Western method on the basis of the summary and reduction in scale of Chongzhen Calendar 崇禎曆書 created in the late period of the Ming dynasty, to the Qing dynasty Xiyang xinfa lishu 西洋新法曆書 ${ }^{44}$. This work not only helped the Chinese people access the astronomical theory and method of calculation as well as the system of knowledge related to the contemporary Western astronomical instruments but was also considered an achievement of cooperation between Jesuit missionaries headed by Johann Adam Schall von Bell and Chinese astronomers in translating Western astronomy works, which opened up to the Chinese learned men the method of calculating the calendar of the West in a more accurate manner than the traditional way. Later, the eighteenth century witnessed the birth of a series of other calendar-astronomical works under the Qing dynasty such as Lixiang

${ }^{42}$ Xu G. Q., Wang Z. M. Xu Guangqi ji (Xia ce) [The complete works of Xu Guangqi (vol. 2)]. Shanghai, 1984. P.374.

${ }^{43}$ Aslaksen $H$. The Mathematics of the Chinese calendar. Department of Mathematics, National University of Singapore. URL: http://citeseerx.ist.psu.edu/viewdoc/download?doi=10.1.1.139.9311\&rep= rep1\&type $=$ pdf $($ accessed 07.10.2019).

${ }^{44}$ Yang Y.P. Qintianjian li de chuanjiaoshi [Missionaries in Bureau of Astronomy] // Wenshizhishi [Literature and History knowledge]. 2002. Vol.4. P. 4. 
Kaocheng 歷象考成 (Summation of measurements and observations ${ }^{45}$ ), Lixiang Kaocheng Houbian 歷象考成后編 (Later volumes of the summation of measurements and observations ${ }^{46}$ ), which were typical examples showing an increasingly deep influence of the Western astronomy on China. In fact, the above-mentioned calendar works were designed and created by Western missionaries working at the Bureau of Astronomy at that time ${ }^{47}$.

Secondly, the Chinese adopted the Western astronomy through the design, manufacture, and improvement of astronomical instruments as well as through the creation and revision of catalogue of stars carried out by the Jesuits during their work at the Bureau of Astronomy of the Ming dynasty and Qing dynasty in the seventeenth and eighteenth centuries. In the late period of the Ming dynasty, the necessity of using Western astronomical instruments for astronomical observations and meteorology to serve the calculation and compilation of the calendar was recognized. Xu Guangqi 徐光啟 — the high-rank mandarin appointed by King Chongzhen 崇禎 to manage the work in the Calendar Bureau 歷局 at that time even petitioned to the king twice in July and September 1629 for his approval of the creation of several Western astronomical instruments that the Chinese had never known before: quadrant, sextant, astrolabe, celestial globe, terrestrial globe, sun-dial, star-dial, telescope $\mathrm{e}^{48}$. After that, the design and manufacture of the astronomical instruments were assigned to the missionaries Johann Schreck 鄧玉涵, Johann Adam Schall von Bell 湯若望, Giacomo Rho 羅雅谷. In 1634, along with the completion of the calendar revision, these astronomical instruments were also made ${ }^{49}$. In particular, the introduction of the telescope into China, through the manufacture activity of Jesuit missioners during this period, considerably supported the process of observing and examining solar and lunar eclipses conducted by Chinese mandarins working at the Bureau of Astronomy of the Ming dynasty. Jesuits not only designed and manufactured the aforementioned astronomical instruments, they also included some information related to them, such as their design, size, texture, function, in the content of Chongzhen Calendar 崇禎曆書 - the main document for Chinese scholars studying Western astronomy ${ }^{50}$ at that time - which facilitated the reception of the Western astronomical achievements by Confucian scholars in the contemporary Chinese society.

In the Qing dynasty, in 1673, a Belgian missionary Ferdinand Verbiest helped the Bureau of Astronomy of this dynasty to successfully manufacture 6 astronomical instruments, including equatorial armillary sphere 赤道經緯儀, ecliptic armillary sphere 黃道 經緯儀, horizon circle 地平經儀, sextant 紀限儀, quadrant 象限儀 and celestial globe

${ }^{45}$ Pegg R. A. The Star Charts of Ignatius Kögler (1680-1746) in the Korean Court // Journal of Jesuit studies. 2019. Vol. 6. P. 46.

46 Ibid.

47 Lixiang Kaocheng 歷象考成 and Lixiang Kaocheng Houbian 歷象考成后編 were compiled and revised by two Jesuit missionaries named Ignaz Kögler and André Pereira. See: Pfister L. Notices biographiques et bibliographiques sur les jésuites de l'ancienne mission de Chine. Vol. 2. P. 647, 653.

${ }_{48} \mathrm{Xu}$ G. Q., Wang Z. M. Xu Guangqi ji (Xia ce) [The complete works of Xu Guangqi (vol. 2)]. Shanghai, 1984. P.336, P.341-342.

${ }^{49} \mathrm{Xu}$ J.L. Ershisi shi quanyi (Di san ce) [The full translation of twenty-four sets of History books (vol.3)]. P. 436.

50 Song J. L. Ming mo liju yu Xixue Dong jian [The Calendar Bureau and the introduction of Western science in the end of Ming dynasty] // Xinyang Shifan Xueyuan Xuebao (Zhexue Shehui kexue ban) [Journal of Xinyang Normal University (Philosophy and Social Sciences Edition)]. 2006. Vol. 4. P. 123. 
天體儀 ${ }^{51}$. Subsequently, from 1713 to 1715 , the German missioner Kilianus Stumpf also helped the Bureau of Astronomy to manufacture a new type of horizon circle combining the features of the two previously used instruments - a quadrant and acelestial globe, and the German missionaries Ignaz Kögler and Augustin Ferdinand von Hallerstein, who worked at the Bureau of Astronomy during the reign of Qianlong Emperor, improved the armillary sphere - turning a traditional Chinese astrological observation instrument into an elaborate equatorial armillary sphere between 1746 and $1754^{52}$ in order to expand its performance and enhance its accuracy in astronomical observations.

In addition, in the seventeenth and eighteenth centuries, a catalogue of stars was created in the Bureau of Astronomy of the Qing dynasty - a task frequently performed by Western astronomers, but not really common to the Eastern astronomy. Undoubtedly, this astronomical work was introduced to China by Jesuit missionaries who also played a leading role in the process of observing, calculating and creating catalogues of stars; thereby the Chinese could expand and acquire a great deal of Western astronomical knowledge. In fact, from 1669 to 1673, at the Bureau of Astronomy of the Qing dynasty, a missionary Ferdinand Verbiest and 31 Chinese astronomers and scholars compiled Ling tai yi xiang zhi 靈臺儀象志, in which equatorial and ecliptic coordinates of more than 1870 fixed stars ${ }^{53}$ were published in volumes 5 to 14 . For more than half a century later (1675-1743), this catalogue of stars played an extremely important role at the Bureau of Astronomy of the Qing dynasty serving as the basis for calculating celestial phenomena. However, in 1744 , due to the discovery that the data of the position of the fixed stars in book Ling tai yi xiang zhi 靈臺儀象志 was incorrect, the German Jesuit missionary Ignaz Kögler, Director of the Bureau of Astronomy, and 26 Chinese astronomical mandarins and scholars working at the Bureau during the Qing dynasty were assigned the task of calculating, revising, correcting and adding to the catalogue of stars created by Ferdinand Verbiest in 16691673 and of compiling the series Yi xiang kao cheng 儀象考成, including 32 volumes, in which up to 30 volumes were catalogues of stars listing 300 constellations and specifying equatorial and ecliptic coordinates of 3083 stars and axial precessions and magnitudes ${ }^{54}$.

Thirdly, the Chinese received the Western astronomy through the compilation and translation of the Western astronomical bibliography into Chinese language by Jesuit missionaries in the seventeenth and eighteenth centuries. Upon arriving in China, Jesuits realized that this was a nation with a long-standing cultural and educational background. Chinese people, especially kings, mandarins and intellectuals in the contemporary society attached great importance to scholarship and bibliography, which made Jesuits think of a unique method of mission - “missionary bibliography 書籍傳教”, i. e. translating or compiling some books related to Western science and technology, including astronomy,

51 Zhang B. C. Ming Qing cetian yiqi zhi Ouhua [The Europeanization of astronomical instruments in the Ming and Qing China]. Shenyang, 2000. P. 161-170. See more: Yao C. S. Qingdai Qintianjian de tianwen gongzuo [Astronomy activities of the Qing dynasty Qintianjian] // Guangxi Minzu Xueyuan xuebao (Ziran kexue ban) [Journal of Guangxi University for Nationalities (Natural Science Edition)]. 2004. Vol.2. P.44; Needham J., Wang L. Science and Civilisation in China. Vol. 3. Cambridge, 1959. P.451-452.

${ }^{52} \mathrm{Pan} N$. Zhongguo gu tianwen yiqi shi [History of Chinese ancient astronomical instruments]. Taiyuan, 2005. P. 184-196.

53 Yao C.S. Qing dai Qintianjian de tianwen gongzuo [Astronomy activities of the Qing dynasty Qintianjian] // Guangxi Minzu Xueyuan xuebao (Ziran kexue ban) [Journal of Guangxi University for Nationalities (Natural Science Edition)]. 2004. Vol.2. P. 44.

54 Ibid. P. 45. 
to serve its mission. In fact, from the end of the sixteenth century to the end of the eighteenth century, many books of various Western scientific and technical fields were compiled or translated into Chinese by Jesuit missionaries ${ }^{55}$. However, astronomy amounted to 89 books $^{56}$, two-thirds of the total number of scientific and technical books compiled and translated at that time ${ }^{57}$. The following table presents some translated or compiled works by Jesuit missionaries in China in the late Ming and early Qing period.

\section{Some typical astronomical bibliographies translated or compiled by Chinese Jesuit missioners in the Chinese language in the late Ming and early Qing period (XVII-XVIII centuries)}

\begin{tabular}{|c|c|c|c|}
\hline No & Name of Jesuit missionaries & Quantity & Name of astronomical works \\
\hline 1 & Matteo Ricci 利瑪竇 & 3 & $\begin{array}{l}\text { Qian kun ti yi (乾坤體義), Jing tian gai (經天該), } \\
\text { Hun gai tong xian tu shuo (渾蓋通憲圖說) }\end{array}$ \\
\hline 2 & $\begin{array}{l}\text { Johann Adam Schall von Bell } \\
\text { 湯若望 }\end{array}$ & 18 & $\begin{array}{l}\text { Chong zhen lishu (崇禎曆書), Hun tian yi shuo } \\
\text { (渾天儀說), Gujin jiaoshi kao (古今交食考), Xiyang } \\
\text { ce ri li (西洋測日曆), Xing tu (星圖), Jiao shi li zhi } \\
\text { (交食歷指), Jiao shi biao (交食表), Ce shi shuo (測 } \\
\text { 食說), Ce tian yueshuo (測天約說), Lifa xi chuan (曆委学 } \\
\text { 法西傳), Xinfa li yin (新法歷引), Xue li xiao bian (學 } \\
\text { 歷小辯), Hengxing biao (恆星表), Hengxing li zhi } \\
\text { (恆星曆指), Hengxing chu mo (恆星出沒), Xinfa } \\
\text { xiao huo (新法曉惑), Xinfa biao yi (新法表異), Min } \\
\text { li bu zhu jie huo (民歷補註解惑) }\end{array}$ \\
\hline 3 & Ferdinand Verbiest 南懷仁 & 12 & $\begin{array}{l}\text { Ceyan ji lue (測驗紀略), Yi xiang zhi (儀象志), Yi } \\
\text { xiang tu (儀象志), Kangxi yong nian lifa (康熙永年 } \\
\text { 曆法), Chidao nan bei xingtu (赤道南北星圖), Jian } \\
\text { ping gui zong xing tu (簡平規總星圖), Ri chu shike } \\
\text { biao (日出時刻表), Lifa budeyi bian (曆法不得已 } \\
\text { 讋), Wang zhan bian (妄佔讋䛨), Wang ze bian (妄擇 } \\
\text { 讋), Wang tui jixiong zhi bian (妄推吉凶之讋), Xi } \\
\text { chao ding an (熙朝定案) }\end{array}$ \\
\hline
\end{tabular}

${ }^{55} \mathrm{Xu}$ Z.Z. Ming Qing jian Yesuhuishi zheyi tiyao [Summary of Jesuits translated works in Ming and Qing dynasties]. Shanghai, 1949.

56 According to the statistics of the author Ma Zhentao 馬振濤, from 1584 to 1790 , the number of Western science and technology bibliographies translated into Chinese by Jesuit missionaries was 137, including 20 mathematical books (14,6\%), 89 astronomical books (65\%), 6 physical books (4,4\%), 8 biological and medical books (5,8\%), 8 military science books (5,8\%), 3 books recording many fields (2,2\%). See: Ma Z. T. "Xixue Dong jian" yu "Dongxue Xi jian" — Ming mo Qing chu chuanjiaoshi keji fanyi de lishi wenhua yujing [Historical and cultural context of missionary sci-tech translation in late Ming and early Qing dynasty] // Yuwen xuekan [Journal of Language and Literature Studies]. 2010. Vol. 8. P. 83. In his study, the author Hu Xianyuan 胡先媛 conducted statistics on more fields, however, the leading position in terms of the number of Western astronomical bibliographies translated into Chinese in the sixteenth, seventeenth and eighteenth centuries kept unchanged compared to other fields of science and technology. See: $H u$ X. Y. Cong "Ming Qing jian Yesuhuishi yizhu tiyao" kan Zhong Xi xueshu jiaoliu [On Chinese and Western Academic Exchange from the perspective of "Summary of Jesuits translated works in Ming and Qing dynasties"] // Sichuan Tushuguan xuebao [Journal of The Sichuan Society for Library Science]. 1996. Vol.6. P.78. See more: Bernard H. Les Adaptations Chinoises D'ouvrages Europeens: Bibliographie Chronologique Depuis la Venue des Portugais à Canton Jusquà la Mission Française de Pékin 15141688 // MonumentaSerica. 1945. Vol. 10. P. 1-57, 309-388.

57 Ma Z. T. "Xixue Dong jian" yu "Dongxue Xi jian" - Ming mo Qing chu chuanjiaoshi keji fanyi de lishi wenhua yujing [Historical and cultural context of missionary sci-tech translation in late Ming and early Qing dynasty] // Yuwen xuekan [Journal of Language and Literature Studies]. 2010. Vol. 8. P. 83. 


\begin{tabular}{|c|c|c|c|}
\hline No & Name of Jesuit missionaries & Quantity & Name of astronomical works \\
\hline 4 & Johann Schreck 鄧玉函 & 3 & $\begin{array}{l}\text { Ce tian yue shuo (測天約說), Huang chi ju du biao } \\
\text { (黃赤距度表), Zheng qiu sheng du biao (正球升度 } \\
\text { 表) }\end{array}$ \\
\hline 5 & Sabatino de Ursis 熊三拔 & 2 & Biao du shuo (表度說), Jian ping yi shuo (簡平儀說) \\
\hline 6 & $\begin{array}{l}\text { Emmanuel Diaz, Junior } \\
\text { 陽瑪諾58 }\end{array}$ & 1 & Tian wen lue (天問略) \\
\hline 7 & $\begin{array}{l}\text { Philippus Maria Grimaldi } \\
\text { 閔明我 }\end{array}$ & 1 & Fang xingtu jie (方星圖解) \\
\hline 8 & Giacomo Rho 羅雅各 & 7 & 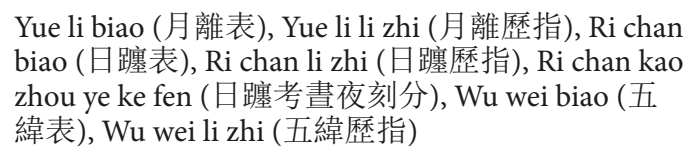 \\
\hline 9 & $\begin{array}{l}\text { Nicolas Smogolenski } \\
\text { 穆尼閣59 }\end{array}$ & 1 & Tian bu zhen yuan (天步真原) \\
\hline 10 & Ludovic Bugli 利類思 60 & 1 & Xi li nian yue (西曆年月) \\
\hline 11 & Ignaz Kögler 戴進賢 & 1 & Li xiang kao cheng (歷象考成) \\
\hline
\end{tabular}

Source: [Zhu Q.Z., 2002, pp.77-79; Xu Z.Z., 1949, pp.230-318].

The compilation and translation of Western astronomical bibliography into the Chinese language by Jesuit missionaries working in China during the seventeenth and eighteenth centuries was generally carried out in the following manner: missionaries orally interpreted the content and Chinese astronomical intellectuals recorded $i^{61}$. It was this combination that enabled Western astronomy to be received by the Chinese. In fact, the astronomical bibliographies compiled and translated by Jesuit missionaries into the Chi-

${ }^{58}$ Emmanuel Diaz Junior 陽瑪諾 was one of the Jesuit missionaries who helped bring Christianity and Western science and technology into China in the late Ming and early Qing periods. He was born in 1574, in Castelblanco (Portugal), died in 1659 in Hangzhou (China). He joined the Jesuits in 1592. In 1610, he went to China to the mission. During the process, he was one of the first missionaries to introduce the telescope to the Chinese people just a few years after it had been invented in the Netherlands (1608). His knowledge of telescope was first presented in China in 1615 in a book in the Chinese language Tiānwènlüè (天問略: Explicatio Sphaerae Coelestis) compiled by him. See: Jami C., Saraiva L. The Jesuits, the Padroado and East Asian science (1552-1773). Singapore, 2008. P. 99; Needham J., Wang L. Science and Civilisation in China. Vol.3. Cambridge, 1959. P. 444; Ma Z. Y. Zhongguo fanyi tongshi (Gudai bufen (quan yi juan)) [A History of Translation in China (Ancient part (all volumes))]. Wuhan, 2006. P. 308.

59 Nicolas Smogolenski 穆尼閣 (1611-1656) was a Polish Jesuit missionary operating in China during the first half of the seventeenth century. In 1635, he joined the Jesuits. In 1646, he went to China to the mission. During his work in this country, he made a significant contribution to spreading Western astronomy and mathematics to Chinese people. On the life and career of Nicolas Smogolenski, see: Pfister L. Notices biographiques et bibliographiques sur les jésuites de l'ancienne mission de Chine. Vol. 1. P. 262-265.

${ }^{60}$ Ludovic Bugli 利類思 (1606-1682) was an Italian Jesuit missionary. In 1622, he joined the Jesuits. In 1637, he went to China to the mission. During his time in this country, he and some other Jesuit missionaries participated in revising the calendar for the Qing dynasty. He died in Beijing in 1682. See: Pfister L. Notices biographiques et bibliographiques sur les jésuites de lancienne mission de Chine. Vol. 1. P. 230-243; Brokey L. M. Journey to the East: The Jesuit Mission to China, 1579-1724. London, 2007. P. 110.

${ }^{61}$ Qian C.X., Dai W.B. Jinshi yishu dui Zhongguo xiandaihua de yingxiang [Impact of bibliographic translation in modern times on Chinese modernization] // Wenxian [The Documentat]. 1986. Vol. 2. P. 180. 
nese language in the seventeenth and eighteenth centuries were accepted by the king, mandarins, and intellectuals of this country and became the theoretical foundation and scientific basis for calculating the calendar, observing and verifying astronomical and meteorological phenomena at the Bureau of Astronomy of two dynasties of the Ming and Qing. The works compiled and translated by contemporary Jesuit missionaries in the country served as concentrated and profound manifestations of the adoption of Western astronomy in China.

In China, the process of adopting Western astronomy from the sixteenth to the eighteenth centuries was realized in many ways and brought about impressive results, while in Vietnam during this period the authorities pursued the policy of banning Christianity and expelling foreign missionaries, which not only continuously interrupted the reception of Western astronomy but also meant that the methods and outcomes of the reception were less diverse, powerful and profound than in China. In fact, Western astronomy made its way into Vietnam in the sixteenth-eighteenth only by the following means: through Jesuit missionaries who explicitly discussed and explained the knowledge of Western astronomy to the rulers of Vietnam, and secondly - by missionaries of this order who, on many occasions, calculated the imminent solar and lunar eclipses and outlined them in drawings informing the king and local officials, and also debated a number of issues related to these phenomena with Vietnamese astronomers.

According to the records of Jesuits in Vietnam in the first half of the seventeenth century, during the years of 1626-1627, two missionaries Giuliano Baldinotti ${ }^{62}$ (Italian) and Alexandre de Rhodes ${ }^{63}$ (French) once conversed with Trinh Lord and some Tonkin mandarins about the solar eclipse, lunar eclipse as well as about the movement of stars in the $s k y^{64}$. The phenomena of solar and lunar eclipses in the mind of the Vietnamese

${ }^{62}$ Giuliano Baldinotti was an Italian Jesuit missionary, born in 1591 in Pistoia, near Florence, who died in 1631 in Macao, China. He joined the Jesuits in 1609. Twelve years later (1621), he set off to the East to the mission. While visiting Macao, where many Portuguese people lived, Baldinotti made a decision to go to Tonkin. On 2 February 1626, he and Portuguese merchants and a Japanese missionary Giulio del Piano departed from Macao and reached the capital of Ke Cho (Tonkin) on 7 March 1626. At that time, Trinh Trang Lord wanted to establish a regular relationship with the Portuguese, so he welcomed Baldinotti and the merchants very kindly. Because of his excellence in astronomy and mathematics, Baldinotti attracted special attention of Lord Trinh, and the Lord asked him to stay longer. During this time, he had the opportunity to go in and out of the royal palace, witness many royal activities and regularly experienced daily life in Ke Cho. However, due to the absence of knowledge of the native language, his mission in Tonkin (Tonkin) at that time failed to achieve results. See: Nguyen H. Lịch sử truyền giáo ở Việt Nam (Tập 1) [Missionary History in Vietnam (vol. 1)]. SàiGòn, 1959. P. 97-98; Baldinotti G. La Relation sur le Tonkin du P. Baldinotti // Bulletin de l'Ecole française d'Extrême-Orient. 1903. Vol.3. P. 71-78.

63 Alexandre de Rhodes was born on 15 March 1593 in Avignon, in a Jewish family. On 14 April 1612, he joined the Jesuits in Rome and was ordained a priest in 1618. At the end of the year, he was accepted by the Jesuit Superior for the mission in Eastern Asia after having applied three times for a missionary trip between 1614 and 1618. He arrived in the Portuguese capital to board the ship to Eastern Asia, but because he was suspended for too long in Goa, until 29 May 1623, he reached Macao. Initially, he planned to go to Japan to the mission, but his wish was unsuccessful, so he was sent to Vietnam. He came to Cochinchina, Vietnam, for the first time in December 1624 and returned to Macao to go to Tonkin, Vietnam, in July 1626. On19 March 1627, he arrived in Tonkin and was expelled from the area in May 1630. From 1630 to 1640, he taught theology at the institute of Madre de Deus. Between 1640 and 1645, he returned to the mission in Cochinchina. In July 1645, he left Cochinchina for Macao and then went to Europe. In 1654, he went to Persia and died at Ispahan on November 5, 1660. See: Do Q. C. Lịch sử chũ Quốc ngũ (1620-1659) [History of the Romanized Vietnamese script (1620-1659)]. P. 106.

${ }^{64}$ Baldinotti G. La Relation sur le Tonkin du P. Baldinotti // Bulletin de l'Ecole française d'ExtrêmeOrient. 1903. Vol.3. P.71-78; Rhodes A. Histoire du Royaume de Tunquin. Lyon, 1651. P. 152-153. 
were considered spiritual, mystical and sacred, with cults, but also instilled terror in the rulers and inhabitants of the missionary land, which gave a rare opportunity for Jesuits to show the miracle, realization and accuracy of the European astronomy, thereby attracting various classes of contemporary Vietnamese society to Christianity. In fact, through the calculation and observation enabling to predict the occurrence of such phenomena Jesuit missionaries gradually brought Western astronomical knowledge to the Vietnamese. In the Histoire du Royaume de Tunquin, the missionary Alexandre de Rhodes mentioned the occurrence of lunar eclipse in 1628 while he was in Tonkin ${ }^{65}$. Accordingly, a few days before the lunar eclipse, he calculated the start and end time of this lunar eclipse and at the same time drew its entire process on paper and tried to pass the images to Lord Trinh. He made it clear to Lord Trinh who conducted "moon rescue ritual" 66 that it was not possible to shorten the time of the lunar eclipse. This made him change his mind and not perform the rituals upon the occurrence of the lunar eclipse as before. And when this phenomenon took place exactly as predicted by Alexandre de Rhodes, Lord Trinh showed his admiration and praised him for his astronomical knowledge ${ }^{67}$. In 1629 , while preaching in Nghe An province, Alexandre de Rhodes also calculated the time of the upcoming solar eclipse and drew its images on August 25, giving notice four days prior to it to the leading mandarin. Everything happened as predicted by Alexandre de Rhodes. That surprised the mandarin of Nghe An province and filled him with admiration for the accurate and authentic understanding of the secrets of the sky and the stars by Alexandre de Rhodes, which completely exceeded the cognitive ability of the Vietnamese people at the time ${ }^{68}$.

Meanwhile, in Cochinchina, documents of Jesuit missionaries working in this area in the early seventeenth century also recorded similar to Tonkin's cases of the process of initial receiving of Western astronomy by the king, mandarins, and intellectuals of this country through the activities of calculation, forecasts of solar and lunar eclipses carried out by the missioners. For example, Cristoforo Borri ${ }^{69}$, a Jesuit missionary, in the report

65 The seventeenth and eighteen centuries were a turbulent period in the Vietnamese history. From 1627 to 1672, Trinh family in the North and Nguyen family in the South fought each other 7 times but failed to come to an end. After 46 years of constant fighting, both sides exhausted their human resources and properties, so they had to accept a truce and a long division. Gianh River, historically known as Linh Giang, became the boundary dividing Dai Viet country into two regions: from Linh Giang to the South called Dang Trong (Cochinchina) under the administration of Lord Nguyen, and from Linh Giang to the North was called Dang Ngoai (Tonkin) under the administration of King Le Lord Trinh. This situation lasted until the end of the eighteenth century when Tay Son peasant movement broke out (1771), which in turn destroyed the force of Lord Nguyen in Cochinchina (1777) and Lord Trinh in Tonkin (1786). See: Truong H. Q., Dinh X. L., Le M. H. Đại cương Lịch sử Việt Nam toàn tập [General History of Vietnam]. Hà Nội, 2006. P. 335-362; Le T.K. Lịch sử Việt Nam từ nguồn gốc đến giữa thế kỉ XX [Vietnam History from the origin to the middle of the $20^{\text {th }}$ century]. Hà Nội, 2014. P. 291-352.

66 During the lunar eclipse or solar eclipse, Vietnamese kings often performed very solemn ceremonies. Firstly, they announced this case across the country. After that, they ordered mandarins and people to gather in the court as well as area to follow the moon and the sun, and when a lunar eclipse and solar eclipse occured, they wore mourning robes, carried on bowing and saying words of mercy to the moon or the sun being swallowed by the dragon. That is the ritual of rescue. See: Borri C. Relation de la nouvelle mission des pères de la compagnie de Jésus au royaume de la CochinChine // Bulletin des Amis du Vieux Hué. 1931. Vol.3-4. P. 373-375; Luis G. Histoire de ce qui s’est passé en Éthiopie, Malabar, Brasil, et les Indes Orientales. P. 122-127.

67 Rhodes A. Histoire du Royaume de Tunquin. Lyon, 1651. P. 195.

68 Ibid. P.237-238.

${ }^{69}$ Christoforo Borri was one of the Western missionaries who helped bring Christianity to Vietnam in the first half of the seventeenth century. He was born in 1583 in Milan (Italy) and died on May 24, 1632 in 
to Cochinchina referred to the occurrence of lunar eclipse on 19 December 1620. Being in Pulucambi (Binh Dinh province), he calculated the time and drew the process of this lunar eclipse before the phenomenon occurred and informed the local officials in Pulucambi. Another Jesuit missionary Francisco de Pina ${ }^{70}$ was operating in Cacciam (Quang Nam province) - the second largest political center in contemporary Cochinchina. He also calculated the time of eclipse and informed the prince of Lord Nguyen in Cacciam. A fierce debate related to whether or not the lunar eclipse would take place as well as the specific time of this phenomenon arose between mandarins, native astronomers and these Jesuits. In particular, before the erroneous prediction by the Vietnamese astronomers about the time of the lunar eclipse, the prince of Lord Nguyen in Cacciam sent his mandarins to consult with Francisco de Pina, and then everything happened as predicted by the missionary ${ }^{71}$. Another debate concerning the time of solar eclipse, which took place on 21 May 1621, and the possibility of observing it in Cochinchina involved Jesuit missioners and astronomers and mathematicians of Lord Nguyen. The missionary Cristoforo Borri informed Lord Nguyen that because of the phenomenon of parallax, the solar eclipse could not be seen this time from Cochinchina. However, as the nature of the parallax was unknown, the astronomers of Lord Nguyen affirmed that the solar eclipse would occur at the time that they had predicted and that it would be fully seen. In fact, everything happened according to Jesuit missionaries' prediction ${ }^{72}$. Afterwards, as recorded by Cristoforo Borri and Gaspar Luis ${ }^{73}$, many astronomers and mathematicians of Lord Nguyen in Hue and of the prince in Cacciam (Quang Nam province) learnt how to calcu-

Rome. In 1601, he joined the Jesuits. In 1618, he went to Cochinchina, Vietnam to serve as a missionary until 1621. In addition to his role as a missionary, he was also a mathematician and astronomer. In the course of preaching the Gospel in Vietnam, he repeatedly used the knowledge of these fields to conquer the faith of the rulers, the intellectuals and the people of the land under the mission. See: Maybon C. B. Notice sur Cristoforo Borri et sur les editions des sa "Relation" // Bulletin des Amis du Vieux Hué. 1931. Vol.3-4. P.269-276; Do Q. C. Lịch sử chữ Quốc ngũ (1620-1659) [History of the Romanized Vietnamese script (1620-1659)]. P.34-35.

${ }^{70}$ Francisco de Pina was one of the Jesuit missionaries who laid the foundation for the introduction and development of Christianity in Vietnam in the early seventeenth century. He was born in 1585 in Guarda, Portugal. In 1605, he joined the Jesuits. In 1617, he went to Cochinchina, Vietnam to the mission. During his time here, he made an effort to learn the local language, became the first Western missionary to use Vietnamese fluently to preach the Gospel and lay the foundation for the Latinization of Vietnamese language in the early seventeenth century. He died in 1625 in Cochinchina after a boat wreck in the offshore waters of Da Nang. See: Dror O., Taylor K. W. Views of Seventeenth-century Vietnam, Christoforo Borri on Cochinchina and Samuel Baron on Tonkin. New York, 2006. P. 36; Zwartjes O. PortugeseMisionary Grammars in Asia, Africa and Brazil, 1550-1800. Amsterdam, 2011. P. 291; Jacques R. Portugese Pioneers of Vietnamese Linguistics. Bangkok, 2002. P. 27, 61-64; Do Q. C. Lịch sử chũ Quốc ngũ̃ (1620-1659) [History of the Romanized Vietnamese script (1620-1659)]. P.26-27; Bartoli D. Dell' historia dellaCompagnia di Giesv La Cina (Terza parte). Rome, 1663. P. 834.

71 Borri $C$. Relation de la nouvelle mission des pères de la compagnie de Jésus au royaume de la CochinChine // Bulletin des Amis du Vieux Hué. 1931. Vol.3-4. P. 376-379.

72 Ibid. P. 379-381.

73 Gaspar Luis (unknown year of birth) was a Portuguese Jesuit missionary who arrived in Cochinchina in 1625 and remained there for 15 years before leaving this missionary land in 1639 . He is also considered one of the founders of the birth of Vietnamese script in Vietnam in the first half of the seventeenth century, when in the reports of the missionary situation in Cochinchina, Vietnam were written in 1621 and 1626, quite a lot of vestiges about the Latinization process of Vietnamese could be found. See: Montézon F., Estève E., Rhodes A., Tissanier J., Saccano M. Mission de la Cochinchine et du Tonkin avec gravure et carte géographique. Paris, 1858. P. 387; Do Q. C. Lịch sử chũ Quốc ngũ̃ (1620-1659) [History of the Romanized Vietnamese script (1620-1659)]. P. 33, 41-44. 
late and observe the solar and lunar eclipses ${ }^{74}$, which was the best opportunity for Western astronomy to enter Vietnam and be accepted positively by the Vietnamese intellectuals in the seventeenth and eighteenth centuries.

Although the aforementioned evidence is not sufficient to reconstruct a comprehensive picture with the concrete results achieved during the process of adoption of the Western astronomy in Vietnam in the seventeenth and eighteenth centuries, it is possible to confirm that the Vietnamese rulers and intellectuals had access to the knowledge of Western astronomy and acquired it to a certain extent thanks to Jesuit missionaries, who explicitly interpreted it and calculated and predicted solar and lunar eclipses. At least, they recognized its superiority over the traditional astronomical knowledge inherited from China and deeply influenced by it. Thus, the Vietnamese kings realized the need of resorting to the Western missionaries in the fields of science and technology in general, and in astronomy in particular, in the eighteenth century, and Lord Nguyen in Cochinchina was one of the typical examples of this tendency ${ }^{75}$.

\section{Conclusion}

To sum up, from the sixteenth to the eighteenth centuries, the process of East-West cultural exchange in China and Vietnam generally produced positive results with the introduction of a series of Western scientific and technological achievements, in which astronomy was one of the most prominent fields. It is of importance that this process in both countries was associated with the names, roles and merits of the Jesuit missionaries as well as the "missionary academic" policy which they pursued in the sixteenth, seventeenth and eighteenth centuries. In fact, in order to realize the purpose of attracting the classes of Chinese and Vietnamese society, especially kings, mandarins and intellectuals to Christianity, Jesuit missionaries, through many other approaches, introduced to the aforementioned social groups a wide range of achievements as well as knowledge of Western science and technology, including astronomy. Therefore, along with fulfilling the missionary purpose, they also simultaneously obtained indispensable results in terms of cultural exchange as Western astronomical achievements were gradually introduced and accepted by the Chinese and Vietnamese. However, the difference in historical and political contexts, especially in the attitude of the ruling forces of two countries towards Christianity and Western missionaries at certain stages, engendered specific characteristics of the processes of receiving Western astronomy in China and Vietnam. From a comparative perspective, the process of adopting Western astronomy in China in the sixteenth, seven-

74 Borri C. Relation de la nouvelle mission des pères de la compagnie de Jésus au royaume de la CochinChine. P. 381; Luis G. Histoire de ce qui s'est passé en Éthiopie, Malabar, Brasil, et les Indes Orientales. P. $122-123$.

75 In the eighteenth century, Lord Nguyen Cochinchina used Jesuit missionaries named Antoine Arnedo, Jean Baptisle Sanna, Sebatien Pices, Francisco de Lima, Joseph Neugebeaur, Jean Siebert, Grueber, Charles Slamenski and Jean Koffler to act as roles of astronomer, mathematician and physician working in Lord Nguyen's palace. See: Saraiva L. Europe and China: Science and Arts in the $17^{\text {th }}$ and $18^{\text {th }}$ Centuries. Singapore, 2013. P. 32-33; Dehergne J. Répertoire des jésuites de Chine de 1552 à 1800. Roma, 1973. P. 16, 137-138, 152, 184, 239-240, 254-255; Montézon F., Estève E., Rhodes A., Tissanier J., Saccano M. Mission de la Cochinchine et du Tonkin avec gravure et carte géographique. P.259, 267, 387-389; Maybon C. B. Histoire moderne du pays d'Annam (1592-1820). P. 141; Li T. N. Nguyễn Cochichina: Southern Vietnam in the Seventeenth and Eighteenth Centuries. New York, 1998. P.72-73. 
teenth and eighteenth centuries was intense, direct and continuous, with Jesuit missionaries playing the leading role in the courts of the Ming and Qing feudal dynasties. Therefore, the achieved results were relatively impressive. By contrast, the constant changes in the attitude of Vietnamese kings towards Christianity and Western missionaries interrupted the process and affected the results of receiving Western astronomy in Vietnam, which were less profound and diverse than in China.

Despite such differences, the processes of adopting Western astronomy in China and Vietnam in the sixteenth, seventeenth and eighteenth centuries still had similarities. It should be noted that both countries had a long history of formation and development of astronomy, and although Western astronomy could show its superiority in terms of science and accuracy, it still couldn't completely replace traditional astronomical foundation which had been in use for a long time. In fact, Chinese and Vietnamese kings, mandarins, and intellectuals, despite showing their openness and thirst for knowledge in acquiring Western astronomy achievements, didn't completely abandon traditional astronomical knowledge and still continued to preserve and maintain it. In the process of coexistence and simultaneous use, Western astronomy and traditional astronomy could not avoid collisions, which had a certain impact on the process of adopting Western astronomy in China and Vietnam from the sixteenth to the eighteenth centuries.

\section{References}

Bai J., Ma X.X. Kangxi di chuan [Biography of Emperor Kangxi]. Zhuhai, Zhuhai chubanshe [Zhuhai, Zhuhai Publishing House], 1995, 362 p. (In Chinese)

Baldinotti G. La Relation sur le Tonkin du P. Baldinotti. Bulletin de l'Ecole française d'Extrême-Orient, 1903, vol. 3, pp. 71-78.

Bangert W. V. A History of the Society of Jesus. Saint Louis, Institute of Jesuit Sources Publ., 1972, 578 p.

Bartoli D. Dell' historia della Compagnia di Giesv La Cina (Terza parte). Rome, Nella Stamperia del Varefe Publ., 1663, 1152 p.

Bernard H. Les Adaptations Chinoises D’ouvrages Europeens: Bibliographie Chronologique Depuis la Venue des Portugais à Canton Jusquà la Mission Française de Pékin 1514-1688. Monumenta Serica, 1945, vol. 10, pp. 1-57, 309-388.

Borri C. Relation de la nouvelle mission des pères de la compagnie de Jésus au royaume de la CochinChine. Bulletin des Amis du Vieux Hué, 1931, vol. 3-4, pp.279-405.

Brokey L. M. Journey to the East: The Jesuit Mission to China, 1579-1724. London, The Belknap Press of Harvard University Press, 2007, 512 p.

Dehergne J. Répertoire des jésuites de Chine de 1552 à 1800. Roma, Institutum Historicum S. I Publ. and Paris, Letouzey et Ané Publ., 1973, 430 p.

Do Q. C. Lịch sử chũ Quốc ngũ (1620-1659) [History of the Romanized Vietnamese script (1620-1659)]. Sài Gòn, Tủ sách Ra Khơi [Saigon, Ra Khoi Bookstore Publ.], 1972, 171 p. (In Vietnamese)

Dror O., Taylor K. W. Views of Seventeenth-century Vietnam, Christoforo Borri on Cochinchina and Samuel Baron on Tonkin. New York, Cornell Southeast Asia Program Publ., 2006, 290 p.

Du Halde J.B. Yesuhuishi Zhongguo shujian ji: Zhongguo huiyi lu (Di yi juan) [Jesuit missionaries letter collection in China: China memoirs (vol. 1)]. Chin. transl. by D. D. Zheng, J. Zhu. Zhengzhou, Daxiang chubanshe [Zhengzhou, Daxiang Publishing House], 2001, 378 p. (In Chinese)

$\mathrm{Du}$ Halde J.B. Yesuhuishi Zhongguo shujianji: Zhongguo huiyilu (Di er juan) [Jesuit missionaries letter collection in China: China memoirs (vol. 2)]. Chin. transl. by D. D. Zheng, J. Zhu. Zhengzhou, Daxiang chubanshe [Zhengzhou, Daxiang Publishing House], 2001, 342 p. (In Chinese)

Dunne G. H. Generation of Giants: The Story of the Jesuits in China in the Last Decades of the Ming Dynasty. Notre Dame, University of Notre Dame Press, 1962, 389 p.

Fang H. Li Zhizao yanjiu [Li Zhizao Research]. Taibei, Shangwu yinshuguan [Taipei, The Commercial Press], 1966, 229 p. (In Chinese) 
Fei L.Z., Feng C. J. Ru Hua Yesuhuishi liezhuan [Biographies of Jesuits entering China]. Shanghai, Shangwu yinshuguan [Shanghai, The Commercial Press], 1938, 211 p. (In Chinese)

Fontana M. Matteo Ricci: A Jesuit in the Ming Court. Maryland, Rowman \& Littlefield Publishers, 2010, $336 \mathrm{p}$.

Gerbillon J.F. Zhang Cheng riji [Jean-François Gerbillon's diary]. Chin. transl. by X. F. Chen. Beijing, Shangwu yinshuguan [Beijing, The Commercial Press], 1973, 99 p. (In Chinese)

Gerstl A., Strasáková M. Unresolved Border, Land and Maritime Disputes in Southeast Asia: Bi- and Multilateral Conflict Resolution Approaches and ASEAN's Centrality. Leiden, Brill Publ., 2016, 340 p.

Guo F.X. Types and Sources of Scientic Instruments in the Imperial Court of the Early Qing Dynasty. Asian Studies, 2015, vol.3, pp.119-138.

Han Q., Wu M. Xi chao chong zheng ji Xi chao ding an (wai san zhong). Beijing, Zhonghua shuju [Beijing, Zhonghua Book Company], 2006, 457 p. (In Chinese)

$\mathrm{Hu}$ X.Y. Cong "Ming Qing jian Yesuhuishi yizhu tiyao" kan Zhong Xi xueshu jiaoliu [On Chinese and Western Academic Exchange from the perspective of "Summary of Jesuits translated works in Ming and Qing dynasties"]. Sichuan Tushuguan xuebao [Journal of The Sichuan Society Forlibrary Science], 1996, vol. 6, pp. 77-80. (In Chinese)

Jacques R. Portugese Pioneers of Vietnamese Linguistics. Bangkok, Orchid Press, 2002, 408 p.

Jami C., Engelfriet P., Blue G. Statecraft and Intellectual Renewal in Late Ming China: The Cross-Cultural Synthesis of Xu Guangqi (1562-1633). Leiden, Brill Publ., 2001, 469 p.

Jami C., Saraiva L. The Jesuits, the Padroado and East Asian science (1552-1773). Singapore, World Scientific Publishing, 2008, $228 \mathrm{p}$.

Južnič S. Liu Songling - Jiu Yesuhui zai jing zuihou yi wei weida de tianwenxuejia [Hallerstein — The last great Astronomer of the Old Jesuit in Beijing]. Chin. transl. by P. P.Zhou. Shanghai, Sanlian shudian [Shanghai, Sanlian Bookstore], 2014, 210 p. (In Chinese)

Laven M. Mission to China: Matteo Ricci and the Jesuit Encounter with the East. London, Faber \& Faber Publisher, 2011, 279 p.

Le T.K. Lịch sử Việt Nam tư nguôn gốc đến giữa thế kỉ XX [Vietnam History from the origin to the middle of the $20^{\text {th }}$ century]. Hà Nội, NXB Thế giới [Hanoi, World Publishing House], 2014, 642 p. (In Vietnamese)

Li J.P. Qing chu shi da yuan an [The ten great unjust case in the early Qing dynasty]. Beijing, Dongfang chubanshe [Beijing, Oriental Publishing House], 1993, 295 p. (In Chinese)

Li M.D., Jin N.G., He G. J., Wang Z.Z., Li S. Li Madou Zhongguo zhaji (Shang ce) [Matteo Ricci's Notes on China (vol.1)]. Beijing, Zhonghua shuju [Beijing, Zhonghua Book Company], 1983, 705 p. (In Chinese)

Li T.N. Nguyễn Cochichina: Southern Vietnam in the Seventeenth and Eighteenth Centuries. New York, Cornell Southeast Asia Program Publ., 1998, 182 p.

Liang Q.C. Zhongguo jin san bai nian xueshu shi [Academical history of China of the last three hundred years] Taiyuan, Shanxi guji chubanshe [Taiyuan, Shanxi Ancient Books Publishing House], 2001, 347 p. (In Chinese)

Liang Z. J. Shuxuejia zhuanlue cidian [Biographical sketch dictionary of mathematicians]. Jinan, Shandong jiaoyu chubanshe [Jinan, Shandong Education Publishing House], 1989, 774 p. (In Chinese)

Liu Y.H. Li Madou deng zaoqi chuanjiaoshi di xueshu chuanjiao celue ji qi wenhua yiyi [Matteo Ricci and the other missionaries' tactical choice and Its Cultural values in late Ming dynasty]. Tianjin Shehui kexue [Tianjin Social Sciences], 2003, vol. 6, pp. 130-135. (In Chinese)

Luis G. Histoire de ce qui s'est passé en Éthiopie, Malabar, Brasil, et les Indes Orientales. Paris, Chez Sebastien Cramoisy Publ., 1628, 451 p.

Ma Z.T. "Xixue Dong jian" yu "Dongxue Xi jian" - Ming mo Qing chu chuanjiaoshi keji fanyi de lishi wenhua yujing ["Xixue Dong jian" and "Dongxue Xi jian" - Historical and cultural context of missionary sci-tech translation in late Ming and early Qing dynasty]. Yuwen xuekan [Journal of Language and Literature Studies], 2010, vol. 8, pp. 83-87. (In Chinese)

Ma Z. Y. Zhongguo fanyi tongshi (Gudai bufen (quan yi juan)) [A History of Translation in China (Ancient part (all volumes))]. Wuhan, Hubei Jiaoyu chubanshe [Wuhan, Hubei Education Publishing House], 2006, 538 p. (In Chinese)

Manguin P.Y. Les Portugais sur les côtes du Viet-Nam et du Campa. Paris, Lécole Française d'ExtrêmeOrient, 1972, $344 \mathrm{p}$. 
Mantienne F. Les relations politiques et commerciales entre la France et la péninsule Indochinoise (XVIIe siècle). Paris, Les Indes Savantes Publ., 2001, 391 p.

Maybon C.B. Histoire moderne du pays d’Annam (1592-1820). Paris, Plon-Nourrit et Cie Éditeurs, 1919, $418 \mathrm{p}$.

Maybon C. B. Notice sur Cristoforo Borri et sur les editions des sa "Relation". Bulletin des Amis du Vieux Hué, 1931, vol. 3-4, pp. 265-275.

Montézon F., Estève E., Rhodes A., Tissanier J., Saccano M. Mission de la Cochinchine et du Tonkin avec gravure et carte géographique. Paris, Charles Douniol Éditeur, 1858, 412 p.

Morgan J.F. The Japanese and the Jesuits: Alessandro Valignano in Sixteenth Century Japan. New York, Routledge Publ., 1993, 238 p.

Needham J., Bray F. Science and Civilisation in China, vol. 6. Cambridge, Cambridge University Press, 1984, $768 \mathrm{p}$.

Needham J., Wang L. Science and Civilisation in China, vol. 3. Cambridge, Cambridge University Press, 1959, $926 \mathrm{p}$.

Nguyen H. Lịch sủ truyền giáo ở Việt Nam (Tập 1) [Missionary History in Vietnam (vol. 1)]. SàiGòn, NXB Hiện tại [Saigon, Current Publishing House], 1959, 306 p. (In Vietnamese)

O'Malley J. W., Bailey C. A., Harris S. J., Kennedy T. F. The Jesuits: Cultures, Sciences, and the Arts, 1540-1773, vol. 1. Torronto, University of Toronto Press, 1999, 746 p.

Pan N. Zhongguo gu tianwen yiqi shi [History of Chinese ancient astronomical instruments]. Taiyuan, Shanxi jiaoyu chubanshe [Taiyuan, Shanxi Education Publishing House], 2005, 307 p. (In Chinese)

Pegg R. A. The Star Charts of Ignatius Kögler (1680-1746) in the Korean Court. Journal of Jesuit studies, 2019, vol. 6, pp. 44-56.

Pei H.X., Xiao R. H. Tianzhujiao shiliu shiji zai Hua chuanjiao zhi [Catholicism in the sixteenth century in China missionary annals]. Shanghai, Shangwu yinshuguan [Shanghai, The Commercial Press], 1938, 340 p. (In Chinese)

Pfister L. Notices biographiques et bibliographiques sur les jésuites de l'ancienne mission de Chine, vol. 1. Shanghai, Imprimerie de la Mission catholique, 1932, $561 \mathrm{p}$.

Pfister L. Notices biographiques et bibliographiques sur les jésuites de l'ancienne mission de Chine, vol. 2. Shanghai, Imprimerie de la Mission catholique, 1934, $430 \mathrm{p}$.

Plattner F.A. Quand l'Europe cherchait l'Asie: Jésuites missionnaires (1541-1785). Paris, Castertman Publishing, 1954, $301 \mathrm{p}$.

Po-chia Hsia R. Matteo Ricci and the Catholic Mission to China, 1583-1610: A short history with document. Indianapolis, Hacketts Publshing Company, 2016, 176 p.

Qian C.X., Dai W. B. Jinshi yishu dui Zhongguo xiandaihua de yingxiang [Impact of bibliographic translation in modern times on Chinese modernization]. Wenxian [The Documentat], 1986, vol.2, pp. 176-204. (In Chinese)

Rhodes A. Divers Voyages et Missions. Paris, Imprimeur ordinaire du Roy \& de la Reyne, 1653, 281 p.

Rhodes A. Histoire du Royaume de Tunquin. Lyon, Chez Iean Baptiste Devenet Publ., 1651, 326 p. (In French)

Ricci M., Trigault N. China in the sixteenth century: the journals of Matthew Ricci, 1583-1610. Engl. transl. by L. J. Gallagher. New York, Random House Publ., 1953, 616 p.

Saccano M. Relation des progrèz de la Foy au royaume de la Cochinchine ès années 1646 et 1647. Paris, Sébastien et Gabriel Cramoisy Publ., 1653, 140 p.

Saraiva L. Europe and China: Science and Arts in the $17^{\text {th }}$ and $18^{\text {th }}$ Centuries. Singapore, World Scientific Publ., 2013, 309 p.

Shi J.H. Tan Ming Qing zhi ji ru Hua Yesuhuishi di xueshu chuanjiao [The missionary academic ways of Jesuits into China at the end of the first period of Qing dynasty]. Neimenggu Shida xuebao [Journal of Inner Mongolia Normal University], 1983, vol.3, pp. 73-78. (In Chinese)

Song J.L. Ming mo liju yu Xixue Dong jian [The Calendar Bureau and the introduction of Western science in the end of Ming dynasty]. Xinyang Shifan Xueyuan Xuebao (Zhexue Shehui kexue ban) [Journal of Xinyang Normal University (Philosophy and Social Sciences Edition)], 2006, vol. 4, pp. 121-124. (In Chinese)

Spence J.D. Emperor of China: Self-Portrait of K'ang-hsi. New York, Vintage Books, a Division of Random House Publ., 1988, 256 p.

Thomaz de Bossierre M. Y. Yesuhuishi Zhang Cheng - Luyi shisi pai wang Zhongguo de wu wei shuxuejia zhiyi [Jesuit Jean-François Gerbillon - One of the five mathematicians sent by Louis XIV to China]. 
Chin. transl. by Xin Y.Zhengzhou, Daxiang chubanshe [Zhengzhou, Daxiang Publishing House], 2009, 185 p. (In Chinese)

Treadgold D.W. The West in Russia and China: Religious and Secular Thought in Modern Times. Vol.2. Cambridge, Cambridge University Press, 1973, 272 p.

Truong B. C. Lịch sử phát triển Công giáo Việt Nam [History of Catholic development in Vietnam]. Nguyệt san Công giáo và Dân tộc [Monthly Journal of Catholicism and Ethnicity], 1999, vol. 56 (8), pp. $102-$ 128. (In Vietnamese)

Truong H. Q., Dinh X. L., Le M. H. Đại cuoong Lịch sử Việt Nam toàn tập [General History of Vietnam]. Hà Nội, NXB Giáo dục [Hanoi, Education Publishing House], 2006, 1175 p. (In Vietnamese)

Xu G.Q., Wang Z.M. Xu Guangqi ji (Xia ce) [The complete works of Xu Guangqi (vol.2)]. Shanghai, Shanghai guji chubanshe [Shanghai, Shanghai Ancient Books Publishing House], 1984, 641 p. (In Chinese)

Xu J.L. Ershisi shi quanyi (Di san ce) [The full translation of twenty-four sets of History books (vol. 3)]. Shanghai, Hanyu da cidian chubanshe [Shanghai, Chinese Dictionary Publishing House], 2004, 2022 p. (In Chinese)

Xu Z.Z. Ming Qing jian Yesuhuishi zheyi tiyao [Summary of Jesuits translated works in Ming and Qing dynasties]. Shanghai, Shanghai shudian chubanshe [Shanghai, Shanghai Bookstore Press], 1949, 482 p. (In Chinese)

Yang Y.P. Qintianjian li de chuanjiaoshi [Missionaries in Bureau of Astronomy]. Wen shi zhishi [Literature and History knowledge], 2002, vol. 4, pp.4-13. (In Chinese)

Yao C.S. Qing dai Qintianjian de tianwen gongzuo [Astronomy activities of the Qing dynasty Qintianjian]. Guangxi Minzu Xueyuan xuebao (Ziran kexue ban) [Journal of Guangxi University for Nationalities (Natural Science Edition)], 2004, vol.2, pp. 43-51. (In Chinese)

Zhang B. C. Ming Qing cetian yiqi zhi Ouhua [The Europeanization of astronomical instruments in the Ming and Qing China]. Shenyang, Liaoning Jiaoyu chubanshe [Shenyang, Liaoning Education Publishing House], 2000, 397 p. (In Chinese)

Zhu Q.Z. Zhu Qianzhi wenji (Di qi juan) [Zhu Qianzhi's collection of works (vol. 7)]. Fujian, Fujian Jiaoyu chubanshe [Fujian, Fujian Education Publishing House], 2002, 561 p. (In Chinese)

Zwartjes O. Portugese Misionary Grammars in Asia, Africa and Brazil, 1550-1800. Amsterdam, John Benjamins Publ., 2011, 359 p. 